\title{
FUNKCIONALNA DIFERENCIJACIJA PROVENIJENCIJA HRASTA CRNIKE NA ISTOČNOJ OBALI JADRANSKOGA MORA
}

\author{
FUNCTIONAL DIFFERENTIATION OF HOLM OAK \\ PROVENANCES IN THE EAST ADRIATIC COAST
}

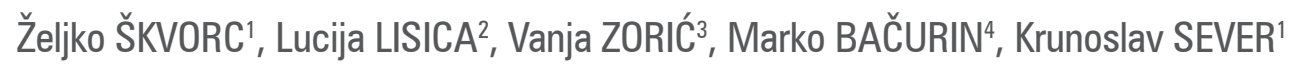

\begin{abstract}
SAŽETAK
Hrast crnika (Quercus ilex L.) je sredozemna vazdazelena vrsta drveća, koja na svom području pridolaska pokazuje veliku morfološku i funkcionalnu varijabilnost. Cilj ovoga rada bio je utvrditi postoji li diferencijacija hrasta crnike na klimatskom gradijentu istočne obale Jadranskoga mora (opisanom s prosječnom godišnjom količinom oborina, prosječnom količinom oborina tijekom ljetnog perioda i klimatskim deficitom vlage) s obzirom na funkcionalne značajke lišća (opisane sa specifičnom lisnom površinom, indeksom relativnog sadržaja ukupnih klorofila u lišću i stopom neto fotosinteze mjerene u lišću). Specifična lisna površina mjerena je na lišću uzorkovanom u tri provenijencije na prirodnom staništu te lišću uzorkovanom u pokusnom nasadu na mladim biljkama porijeklom iz tih istih provenijencija. U pokusnom nasadu mjeren je i indeks relativnog sadržaja ukupnih klorofila i stopa neto fotosinteze. Provenijencija Pula u odnosu na provenijencije Zadar i Bar ima veću specifičnu lisnu površinu te manji indeks relativnog sadržaja ukupnih klorofila i stopu neto fotosinteze. To potvrđuje prilagodbu provenijencije Pula na vlažnije stanište, a provenijencija Zadar i Bar na suše stanište te ujedno ukazuje na funkcionalnu diferencijaciju provenijencija hrasta crnike na istočnoj obali Jadranskoga mora s obzirom na klimatske prilike. Isti obrazac diferencijacije prema specifičnoj lisnoj površini u prirodnim sastojinama i pokusnom nasadu ukazuje na ekotipsku diferencijaciju istraživanih provenijencija. Prema tomu, hrast crnika mogao bi imati značajnu mogućnost funkcionalne prilagodbe na promijenjene klimatske uvjete.
\end{abstract}

KLJUČNE RIJEČI: Quercus ilex L., sklerofilni list, specifična lisna površina, stopa neto fotosinteze, klima

\section{UVOD}

\section{INTRODUCTION}

Vazdazelene sklerofilne drvenaste vrste tipična su komponenta sredozemne vegetacije. Pritom se pojam sklerofilne vrste odnosi na specifičnu građu lišća koje je tvrdo, kožasto, površinom malo i debelo na presjeku (Gil-Pelegrín i dr. 2017). Vrste koje imaju takvu građu lišća čine homogenu funkcionalnu skupinu, čija je specifična građa lista nastala kroz evolucijsku prilagodbu na specifične stanišne uvjete (Traiser et al., 2004). Naime, list kao primarni fotosintetski organ mora biti optimalno prilagođen konkretnim stanišnim uvjetima, odnosno prilikom promjene tih uvjeta list mora imati mogućnost prilagodbe svoje građe kako bi se jedinci omogućilo preživljavanje.

${ }^{1}$ Prof. dr. sc. Željko Škvorc, Doc. dr. sc. Krunoslav Sever, Sveučilište u Zagrebu, Fakultet šumarstva i drvne tehnologije. Zavod za šumarsku genetiku, dendrologiju i botaniku. Svetošimunska 25, HR-10000 Zagreb

${ }^{2}$ Lucija Lisica, univ. bacc. ing. silv., Umeå University. Department of Plant Physiology. Umeå 90183, Švedska

${ }^{3}$ Vanja Zorić, Vinkovićeva 3, HR-10000 Zagreb

${ }^{4}$ Marko Bačurin, mag. ing. silv., Stepanska 3, HR-10412 Donja Lomnica

Korespodencija: Krunoslav Sever, e-mail:ksever@sumfak.hr 
Dugotrajne ljetne suše jedan su od glavnih ekoloških čimbenika koji ograničavaju rast i pridolazak biljnih vrsta u sredozemnom području (Mediavilla i Escudero 2003, Nardini i dr. 2014, Niinemets i Keenan 2014). Kako se različite morfološke i fiziološke značajke biljnih vrsta često interpretiraju kroz prilagodbe na različite ekološke čimbenike, tako se i prisutnost tvrdog i debelog lišća sa smanjenom transpiracijskom površinom kod mediteranskih drvenastih vrsta obično objašnjava kao funkcionalna prilagodba koja im omogućuje preživljavanje jakog sušnog stresa tijekom ljeta (Lamont i dr. 2002, Baldocchi i Xu 2007, Sardans i Peñuelas 2013).

Sklerofilnost lišća se u radovima koji se bave ekofiziološkim i funkcionalnim značajkama biljaka najčešće kvantitativno izražava kao odnos površine i mase suhe tvari lista (specifična lisna površina, SLA) ili odnos mase suhe tvari i površine lista (lisna masa po površini, LMA). Prethodno opisani parametri smatraju se vrlo kvalitetnim pokazateljem sklerofilnosti lišća, iako izravno ne odražavaju mehaničke značajke lišća, nego se više odnose na alokaciju mase i procese povezane s alokacijom mase (Gil-Pelegrín i dr. 2017). Ranija istraživanja pokazala su da je manja specifična lisna površina, odnosno veća lisna masa po površini povezana s većom sklerofilnošću lišća, odnosno s većom aridnošću staništa (Lamont 2002, Gil-Pelegrín i dr. 2017).

Hrast crnika (Quercus ilex L.) je vazdazelena vrsta drveća prirodno rasprostranjena u Sredozemlju, od Portugala i Maroka na zapadu do zapadne obale Turske na istoku, a sjeverni dio njezina areala doseže obalu Atlanskog oceana u zapadnoj Francuskoj. Na tom velikom području dolazi u vrlo različitim tipovima mediteranske klime, od poluaridne do vrlo humidne te od vruće do vrlo hladne na višim nadmorskim visinama (De Rigo i Caudullo 2016). Na istočnoj obali Jadranskoga mora pridolazi na toplijim lokalitetima uz obalu Istre i na sjevernojadranskim otocima, dok na južnojadranskim otocima i na uskom obalnom dijelu južnije od Zadra uglavnom ima kontinuiran areal.

Na tako velikom području pridolaska hrast crnika pokazuje veliku morfološku i funkcionalnu varijabilnost, pa se pojedine populacije diferenciraju s obzirom na klimatske uvjete u kojima pridolaze. To je vrlo dobro istraženo u zapadnom i središnjem dijelu njezina areala (Gratani i dr. 2003, Peguero-Pina i dr. 2014, Varone i dr. 2016), dok su podaci za istočni dio, pa tako i za istočnu obalu Jadranskoga mora vrlo oskudni (Niinemets 2015). Tako velika morfološka i funkcionalna varijabilnost hrasta crnike odražava njezinu veliku fenotipsku plastičnost, koja se definira kao sposobnost pojedinih genotipova da prilagode svoj fenotip kroz morfološke i/ili fiziološke modifikacije, s ciljem da se prilagode promjeni ustaljenih okolišnih prilika (Sultan 2000). Iako je fenotipska plastičnost uvjetovana okolišem, ona može imati i genetsku podlogu kroz lokalnu adaptaciju na ustaljene okolišne uvjete $\mathrm{u}$ različitim dijelovima areala vrste. Prema tomu, lokalna adaptacija kroz prirodnu selekciju dovodi do genetskih promjena kod pojedinih populacija (de Jong 2005), odnosno diferencijacije populacija koje se tada mogu smatrati različitim ekotipovima unutar areala neke vrste (Varone i dr. 2015). Iz navedenog proizlazi da diferencijacija populacija utvrđena u prirodnim sastojinama može biti rezultat genetičkih razlika ili okolišno uvjetovane fenotipske plastičnosti, a često puta je rezultat kombinacije obaju čimbenika.

S obzirom na oskudne literaturne izvore o morfološkim i fiziološkim značajkama populacija hrasta crnike na istočnoj obali Jadranskoga mora, cilj ovoga rada bio je utvrditi postoji li diferencijacija hrasta crnike na klimatskom gradijentu istočne obale Jadranskoga mora s obzirom na funkcionalne značajke njezina lišća. Kako bi se utvrdila genetska pozadina dobivenog uzorka diferencijacije, funkcionalne značajke mjerene su na lišću uzorkovanom u tri provenijencije na prirodnom staništu te lišću uzorkovanom na mladim biljkama porijeklom iz tih istih provenijencija, prethodno uzgojenih u kontroliranim uvjetima.

\section{MATERIJAL I METODE MATERIAL AND METHODS}

\section{Klimatske prilike na lokalitetima istraživanih provenijencija - Climatic conditions at the localities of the studied provenances}

Istraživanje je provedeno na tri provenijencije hrasta crnike s područja Pule $\left(44,88^{\circ} \mathrm{N} ; 13,83^{\circ} \mathrm{E}\right)$ i Zadra $\left(43,99^{\circ} \mathrm{N}\right.$; $\left.15,40^{\circ} \mathrm{E}\right)$ u Republici Hrvatskoj te Bara $\left(42,05^{\circ} \mathrm{N} ; 19,14^{\circ} \mathrm{E}\right)$ u Crnoj Gori koje su smještene na geografskom i klimatskom gradijentu duž istočne obale Jadranskog mora. Prema Köppen-ovoj klasifikaciji klime Pula se nalazi u području Cfs's"a klimatskoga tipa koji se odnosi na umjereno toplu vlažnu klimu s vrućim ljetom, gdje je najveća količina oborina u jesen s jednim manjim sušnim razdobljem ljeti. Zadar i Bar se nalaze u području Csa klimatskoga tipa koji se odnosi na sredozemnu klima s vrućim ljetom i blagom zimom s izrazito najvećom količinom oborina tijekom zime i izrazitim sušnim razdobljem ljeti (Seletković i dr. 2011). Provenijencija Bar odlikuje se najvišom prosječnom godišnjom temperaturom zraka $\left(15.8^{\circ} \mathrm{C}\right)$ i prosječnom godišnjom količinom oborina $(1425 \mathrm{~mm}) \mathrm{u}$ odnosu na Zadar $\left(14,7^{\circ} \mathrm{C}, 860 \mathrm{~mm}\right)$ i Pulu $\left(14,8^{\circ} \mathrm{C}, 836 \mathrm{~mm}\right)$. Međutim, tijekom najtoplijeg i najsušeg dijela godine oborine su raspoređene na drugačiji način, pa tako tijekom ljetnog perioda provenijencija Bar ima najmanju prosječnu količinu oborina (137 mm) u odnosu na Zadar (141 mm) i Pulu (157 $\mathrm{mm}$ ) (usp. Slika 1A, B). Klimatske značajke istraživanih provenijencija dobivene su pomoću ClimateEU (v. 4.63) (http://tinyurl.com/ClimateEU) za razdoblje 1981-2009. 
Uzorkovanje lišća, sakupljanje žira i osnivanje pokusnog nasada - Leaf sampling, acorn collection and experiment establishment

Tijekom zime 2019. godine u svakoj je provenijenciji sa 12 stabala međusobno udaljenih više od 50 metara uzorkovano 12 zdravih, potpuno razvijenih listova s osvjetljenog dijela krošnje s ciljem kasnije analize njihovih morfoloških značajki (površina lista i masa suhe tvari lista). Ispod tih stabala sakupljen je žir koji je posađen u kontejnere prethodno ispunjene mješavinom supstrata za rast biljaka (20\%) i perlita (80\%). Iz tog žira tijekom proljeća 2020. godine razvile su se mlade biljke s kojima je osnovan pokusni nasad. Mlade biljke svih provenijencija uzgajane su u plasteniku pod utjecajem istih okolišnih uvjeta (temperatura zraka, relativna vlažnost zraka, intenzitet osvjetljenja i dr.) te su uredno zaljevane svaki četvrti dan tijekom cijelog vegetacijskoga razdoblja 2020. godine počevši od trenutka proklijavanja žira. U pokusu su rasle ukupno 64 biljke, od toga po 22 biljke iz provenijencija Pula i Zadar, te 20 biljaka iz provenijencije Bar. $U$ drugom dijelu vegetacijskoga razdoblja 2020. godine kada se lišće mladih biljaka u potpunosti razvilo sa svake je biljke uzorkovan po jedan list s ciljem analize njihovih morfoloških značajki (površina lista i masa suhe tvari lista).

\section{Utvrđivanje specifične lisne površine - Specific leaf area determination}

Lišću uzorkovanom u prirodnim sastojinama i pokusnom nasadu pomoću softwaerskog paketa WinFOLIA (WinFolia 2001) izmjerena je površina. Nakon toga lišće je sušeno na temperaturi od $60^{\circ} \mathrm{C}$ do konstantne mase u suhom stanju, za što je bilo potrebno oko 72 sata. Nakon sušenja svakom pojedinačnom listu utvrđena je masa pomoću laboratorijske vage s preciznošću od $0,01 \mathrm{~g}$. Na temelju izmjerene površine i mase suhe tvari za svaki je uzorkovani list izračunata specifična lisna površina (SLA) kao odnos njegove površine $\left(\mathrm{m}^{2}\right)$ i mase (kg), (Pérez-Harguindeguy i dr. 2013).

Izmjera fizioloških značajki u pokusnom nasadu Physiological measurement in the greenhouse experiment

$\mathrm{Na}$ jednom listu svake biljke zastupljene u pokusnom nasadu mjerena je stopa neto fotosinteze (A), a indeks relativnog sadržaja ukupnih klorofila (CCI) na tri lista po biljci. Mjerenja su obavljena u dva navrata tijekom vegetacijskoga razdoblja 2020. godine, točnije 22. srpnja i 24. rujna. Stopa neto fotosinteze mjerena je pomoću prijenosnog uređaja za izmjeru izmjene plinova $\left(\mathrm{CO}_{2} \mathrm{i}_{2} \mathrm{O}\right)$ između bilike i okolne atmosfere LCpro+ (ADC BioScentific, 2007). Svaki list tijekom izmjere A bio je izložen intenzitetu osvjetljenja od $1500 \mu \mathrm{mol}$ fotona $\mathrm{m}^{-2} \mathrm{~s}^{-1}$, koncentraciji $\mathrm{CO}_{2}$ od $380 \pm 10$ $\mu \mathrm{mol} \mathrm{mol}{ }^{-1} \mathrm{i}$ temperaturi zraka od $25 \pm 2{ }^{\circ} \mathrm{C}$. Indeks relativnog sadržaja ukupnih klorofila u lišću mjeren je pomoću prijenosnog optičkog klorofilmetra CCM-200 (Opti-Sciences, Tyngsboro, MA) na pet mjesta po jednom listu (čija je prosječna vrijednost predstavljala CCI cijelog lista, odnosno cijele biljke) izbjegavajući glavnu žilu.

\section{Statistička analiza - Statistical analysis}

Za sve izmjerene varijable, SLA, A i CCI napravljena je deskriptivna statistička analiza. Za izračunavanje značajnosti razlika između provenijencija za svaku pojedinu varijablu korištena je analiza varijance (ANOVA). Prilikom analiziranja varijabli utvrđenih u prirodnim sastojinama (SLA) faktori su bili provenijencija i stablo, gdje je faktor stablo bilo ugnježđeno u faktor provenijencija. Prilikom analiziranja varijabli (SLA, A i CCI) prikupljenih u pokusnom nasadu faktor je bila provenijencija. Značajnost razlika između provenijencija ispitana je pomoću Tukey-evog testa višestrukih usporedbi aritmetičkih sredina. Sve statističke analize provedene su pomoću programskog paketa STATISTICA (TIBCO Software Inc. 2018).

\section{REZULTATI RESULTS}

Analizom varijance utvrđena je statistički značajna razlika $(p<0,05)$ između istraživanih provenijencija za većinu mjerenih značajki kako na lišću uzorkovanom na prirodnom staništu tako i na mladim biljkama u pokusnom nasadu. Izuzetak predstavljaju, masa suhe tvari lišća na prirodnom staništu, površina lišća u pokusnom nasadu i A izmjerena u pokusnom nasadu 24. rujna 2020. godine (drugo mjerenje).

S obzirom na sklerofilnost lišća istraživane provenijencije se na istovjetan način diferenciraju na osnovi uzoraka s prirodnog staništa, kao i uzoraka s klijanaca iz pokusnog nasada. Prema tomu, lišće iz Pule ima statistički značajno veću SLA u odnosu na druge dvije provenijencije. Zadar ima prosječno najniži SLA iako između Zadra i Bara nema značajne razlike (usp. Slika 1C).

U oba mjerenja CCI u pokusnom nasadu (22.7. i 24.9.) provenijencije su pokazale isti obrazac diferencijacije. Najmanji prosječni CCI ima provenijencija Pula, a najveći Zadar. Provenijencija Bar ima vrijednosti između druge dvije provenijencije i statistički značajno se ne razlikuje od njih (usp. Slika 2B). Ovakav obrazac diferencijacije provenijencija zabilježen je i u prvom mjerenju A. U drugom mjerenju A zabilježen je isti poredak provenijencija, međutim prosječne vrijednosti provenijencija se međusobno približuju te između njih više nije bilo statistički značajnih razlika (Slika 2C).

\section{RASPRAVA DISCUSSION}

Brojna istraživanja u području ekofiziologije drvenastih vrsta bave se istraživanjem razlika njihovih funkcionalnih 

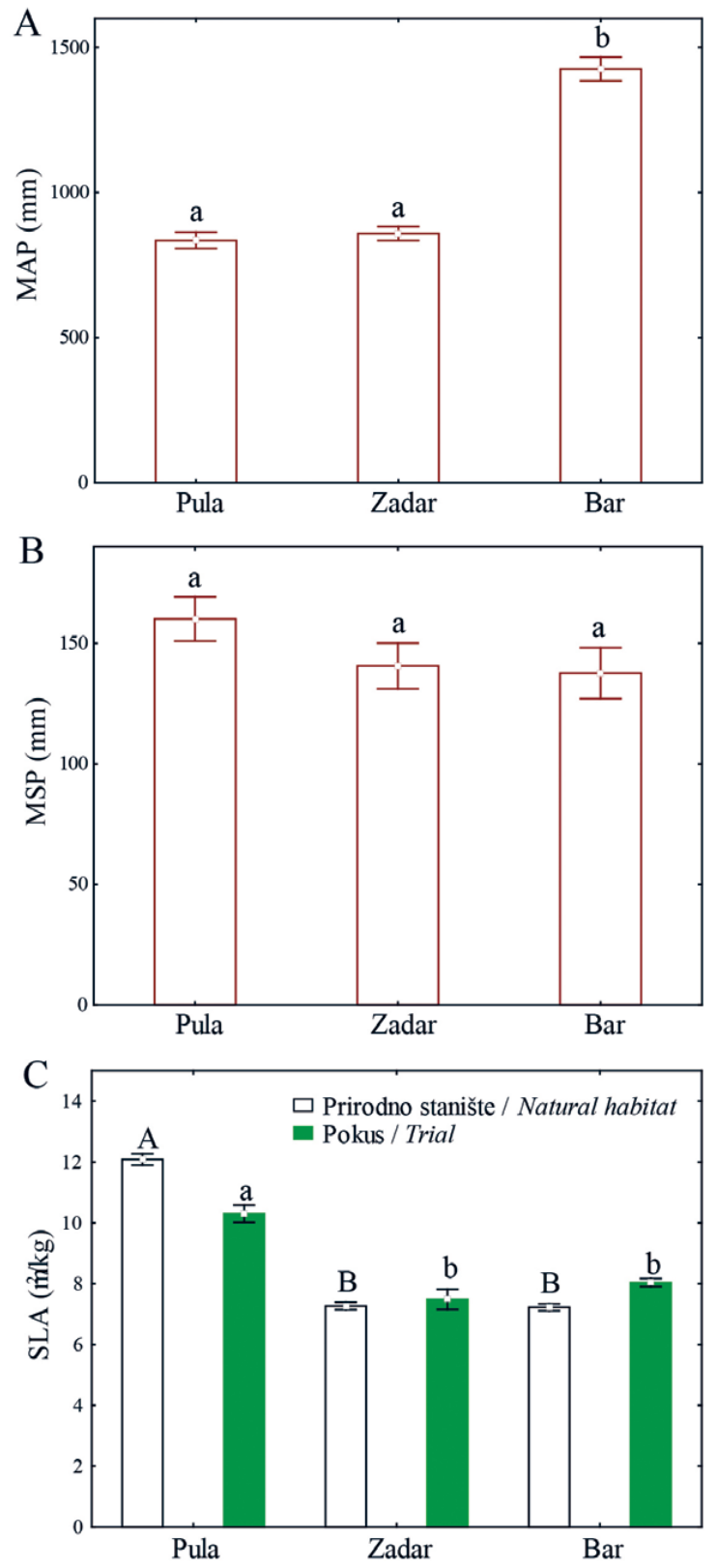

Slika 1. A Prosječna godišnja količina oborina (MAP); B Prosječna količina oborina tijekom ljetnog perioda (MSP); C Specifična lisna površina (SLA) na prirodnom staništu i u pokusnom nasadu. Visina stupca označava aritmetičku sredinu, a gornja i donja horizontalna linija označava \pm standardnu pogrešku. Različita slova na dijagramu označavaju značajne razlike između provenijencija. Na $\mathbf{C}$ velika slova se odnose na prirodno stanište, a mala na pokusni nasad (Tukey-ev test, $p<0,05$ ).

Picture 1 A Mean annual precipitation (MAP); B Mean summer precipitation (MSP); C Specific leaf area (SLA) in natural habitats and trial. Bar indicate provenance mean and whiskers indicate \pm standard error. Different letters indicate significant differences among provenances. Upper-case on $\mathbf{C}$ indicate natural habitat and lower-case indicate trial (Tukey test, $p<0.05$ ).

značajki (Traiser i dr. 2004, Gil-Pelegrín i dr. 2017), međutim uočeno je da unutar pojedinih vrsta postoji značajna diferencijacija provenijencija s obzirom na njihove funkcionalne značajke koje nastaju kao prilagodba različitim stanišnim uvjetima (Niinemets 2015). Dosadašnja istraživanja hrasta crnike ukazuju da postoji značajna funkcionalna diferencijacija provenijencija na različitim klimatskim gradi-
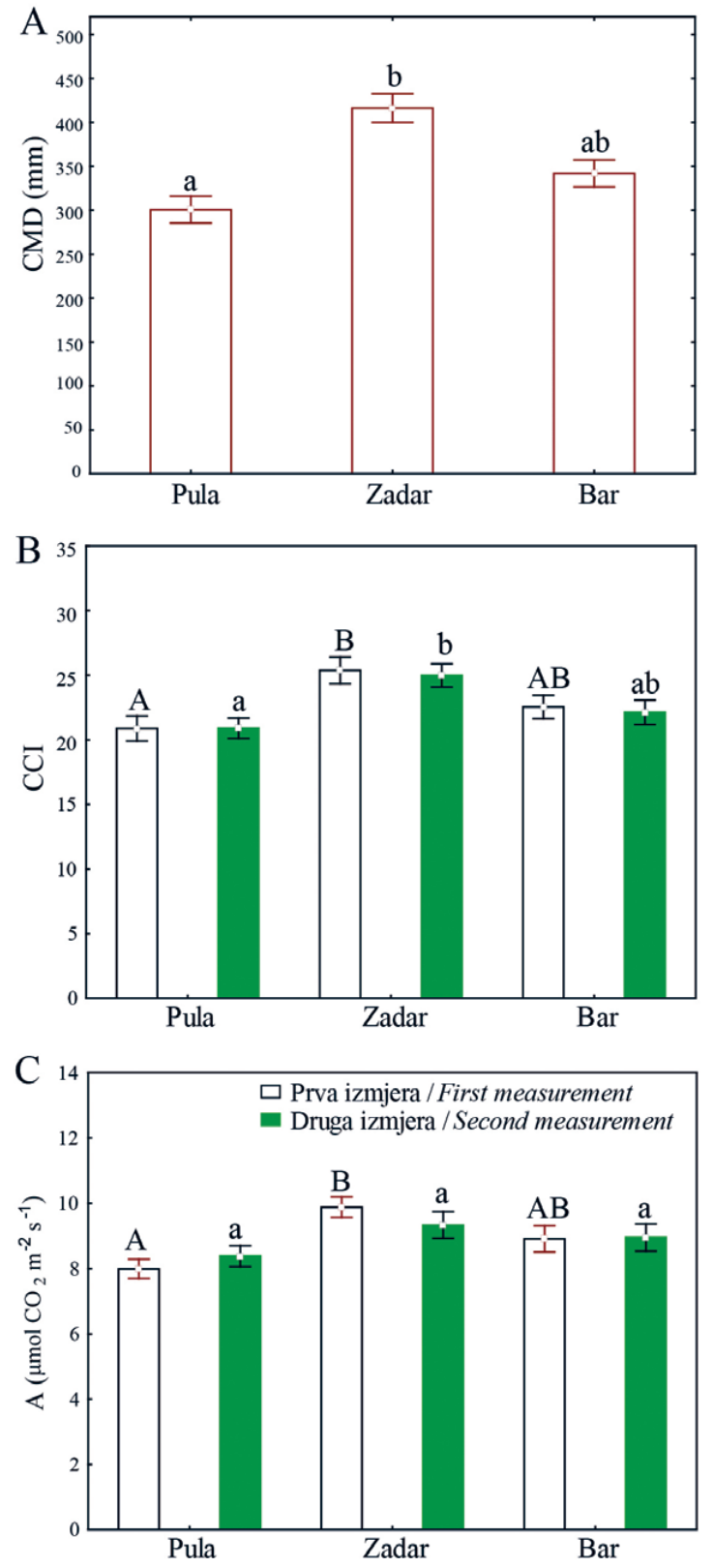

Slika 2. A Deficit klimatske vlage (CMD); B Intenzitet fotosinteze (A); C Indeks sadržaja klorofila (CCI). Visina stupca označava aritmetičku sredinu, a gornja i donja horizontalna linija označava \pm standardnu pogrešku. Različita slova na dijagramu označavaju značajne razlike između provenijencija. Na B i C velika slova se odnose na mjerenje u srpnju, a mala na mjerenje u rujnu (Tukey-ev test, $\mathrm{p}<0,05$ ).

Picture 2 A Climatic moisture deficit (CMD); B Photosynthetic rate (A); C Chlorophyll content index (CCI) in natural stands and trial. Bar indicate provenance mean and whiskers indicate \pm standard error. Different letters on and $\mathbf{C}$ indicate significant differences among provenances. Upper-case indicate measurement conducted in July and lower-case in September (Tukey test, $p<0.05$ )

jentima u središnjem i zapadnom Sredozemlju (PegueroPina i dr. 2014, Niinemets 2015, Varone i dr. 2015), dok naši rezultati to potvrđuju i na istočnoj obali Jadranskoga mora (Slika 1 i 2).

Pri istraživanju funkcionalnih značajki biljaka na prirodnom staništu uvijek se postavlja pitanje koliko je utvrđena varijabilnost, odnosno diferencijacija populacija rezultat okolišno 
uvjetovane fenotipske plastičnosti ili stvarnih genetičkih razlika. Pokusni nasadi sa španjolskim provenijencijama hrasta crnike ukazuju da se fenotipske razlike između provenijencija zadržavaju kada se biljke uzgajaju u istim stanišnim uvjetima (Valladares i dr. 2000, 2002, Gimeno i dr. 2009). To potvrđuju rezultati našeg istraživanja prema kojemu klijanci u pokusnom nasadu zadržavaju isti obrazac diferencijacije s obzirom na SLA kao i njihova majčinska stabla u prirodnim sastojinama (Slika 1C). Takav rezultat ukazuje da je diferencijacija provenijencija hrasta crnike barem djelomično rezultat genetičke prilagodbe na lokalne stanišne uvjete, odnosno da bi kod hrasta crnike na istočnoj obali Jadrana kao i u drugim dijelovima njegova areala mogli razlikovati ekotipove. Kako bi dobili jasniji uvid u ekotipsku diferencijaciju hrasta crnike, u ovom dijelu njegova areala potrebno je provesti istraživanja na većem broju provenijencija te pratiti veći broj funkcionalnih i drugih značajki.

U velikom broju dosadašnjih istraživanja utvrđena je veza između funkcionalnih značajki lišća i klimatskih prilika na prirodnom staništu istraživanih vrsta (Niinemets 2001, Wright i dr. 2004, 2005, Reich i dr. 2007). Prema tim istraživanjima povećanjem prosječne godišnje količine oborina na nekom staništu povećava se površina lišća (Peppe i dr. 2011), odnosno smanjuje se sklerofilnost lišća izražena odnosom površine lista i mase suhe tvari lista (veći SLA, odnosno manji LMA) (Lamont i dr. 2002, Wright i dr. 2004, 2005). U našem istraživanju sklerofilnost lišća koju opisuje SLA (Slika 1C) ne podudara se s prosječnom godišnjom količinom oborina (Slika 1A), nego s količinom oborina u ljetnom periodu (Slika 1B) i klimatskim deficitom vlage (Slika 2A). Naime provenijencija Pula na prirodnom staništu i pokusnom nasadu ima najveću SLA (Slika 1C) iako se njezino prirodno stanište odlikuje najmanjom prosječnom godišnjom količinom oborina (Slika 1A). Međutim provenijencija Pula pridolazi u području umjereno tople vlažne klime, gdje je raspored oborina povoljniji u odnosu na druge dvije provenijencije koje pridolaze na području sredozemne klime (Seletković i dr. 2011). Prema tome, na području Pule znatno je manje izraženo ljetno sušno razdoblje (Seletković i dr. 2011), na što ukazuju i klimatski parametri prema kojima to područje ima manje aridnu klimu u odnosu na Zadar i Bar (Slika 2A).

Utvrđeni obrazac diferencijacije provenijencija s obzirom na SLA i klimatske prilike prati i A izmjerena na klijancima u pokusnom nasadu. Stoga Pula koja ima najvišu SLA i dolazi u najmanje aridnim klimatskim uvjetima ima najnižu A, dok Zadar koji ima najnižu SLA i dolazi u najaridnijim uvjetima ima najvišu A (Slike 1 i 2). Ovakva veza između fotosinteze i SLA nije u skladu s općeprihvaćenim mišljenjem da manji SLA ima negativan utjecaj na intenzitet fotosinteze (Wright i dr. 2004, 2005). Naime, biljke sa sklerofilnijim lišćem (nižom SLA) moraju uložiti više resursa u izgradnju nefotosintetskih tkiva i mezofil takvog lišća manje je učinkovit tijekom fotosinteze (Niinemets i dr. 2009). Međutim prema ranijim istraživanjima intenzitet fotosinteze iskazan po jedinici površine lista kod hrasta crnike opada s povećanjem SLA (Niinemets 2015, Peguero-Pina i dr. 2017), što je u skladu s našim rezultatima (Slika 1C i 2C). Naime, anatomska građa lišća hrasta crnike prilagođena je na način da ono lišće koje ima manju SLA ima i bolju provodljivost $\mathrm{CO}_{2}$ kroz mezofil lista, a provodljivost $\mathrm{CO}_{2} \mathrm{kroz}$ mezofil lista je jedan od ključnih parametara koji reguliraju intenzitet fotosintetskih procesa (Peguero-Pina 2017). Osim bolje provodljivosti $\mathrm{CO}_{2}$ kroz mezofil, lišće hrasta crnike koje ima manju SLA sadrži više dušika po jedinici površine (Niinemets 2015, Peguero-Pina i dr. 2017).

U skladu s tim, provenijencije Zadar i Bar u odnosu na provenijenciju Pula imale su nižu SLA (Slika 1C) i viši CCI (Slika 2B), koji je prema Sever i dr. $(2016,2018)$ u snažnoj pozitivnoj korelaciji sa sadržajem dušika u lišću šumskoga drveća. S obzirom da je većina dušika u lišću vezana za enzime koji sudjeluju u procesima fotosinteze, posebice za enzim RUBISCO koji je najobilniji (Evans 1989), veći sadržaj dušika u lišću zasigurno pozitivno utječe na njegovu fotosintetsku aktivnost. Prema tomu, veći CCI u kombinaciji s manjim SLA, odnosno već ranije spomenutim anatomskim prilagodbama s cijem povećane provodljivosti $\mathrm{CO}_{2}$ kroz mezofil lišća (Niinemets 2015, Peguero-Pina i dr. 2017) objašnjava veću A kod provenijencija Zadar i Bar u odnosu na provenijenciju Pula (Slika 2C).

\section{ZAKLJUČAK CONCLUSION}

Provenijencija Pula u odnosu na provenijencije Zadar i Bar ima veću SLA (manju sklerofilnost lišća) te manji CCI i A (izraženu po jedinici površine lista). To potvrđuje prilagodbu provenijencije Pula na vlažnije stanište, a provenijencija Zadar i Bar na suše stanište te ujedno ukazuje na funkcionalnu diferencijaciju provenijencija hrasta crnike na istočnoj obali Jadranskoga mora s obzirom na klimatske prilike. Štoviše, isti obrazac diferencijacije prema SLA u prirodnim sastojinama i pokusnom nasadu ukazuje na ekotipsku diferencijaciju istraživanih provenijencija. Prema tomu, hrast crnika mogao bi imati značajnu mogućnost funkcionalne prilagodbe na različite klimatske uvjete. $U$ skladu s tim, prilikom razmatranja utjecaja klimatskih promjena na prirodne populacije hrasta crnike u obzir bi trebalo uzeti njegovu fenotipsku plastičnost, ali i uočenu funkcionalnu ekotipsku diferencijaciju.

\section{LITERATURA}

\section{REFERENCES}

- Baldocchi, D., L. Xu, 2007: What limits evaporation from Mediterranean oak woodlands- the supply of moisture in the soil, 
physiological control by plants or the demand by the atmosphere? Adv Water Resour, 30: 2113-2122.

- de Jong, G., 2005: Evolution of phenotypic plasticity: patterns of plasticity and the emergence of ecotypes, New Phytol, 166: 101-117.

- de Rigo, D., G. Caudullo, 2016: Quercus ilex in Europe: distribution, habitat, usage and threats, U: J. San-Miguel-Ayanz, D. de Rigo, G. Caudullo, T. Houston Durrant, A. Mauri (ur.), European Atlas of Forest Tree Species, Publ. Off. EU, Luxembourg, pp. e014bcd+.

- Evans, J. R., 1989: Photosyntesis and nitrogen relationsheep in leaves C3 plants. Oecologia, 78: 9-19.

- Gil-Pelegrín, E., M. Á. Saz, J. M. Cuadrat, J. J. Peguero-Pina, D. Sancho-Knapik, 2017: Oaks under Mediterranean-type climates: functional response to summer aridity, U: Gil-Pelegrín, E., M. Á. Saz, J. M. Cuadrat, J. J. Peguero-Pina, D. SanchoKnapik (ur.), Oaks physiological ecology. Exploring the functional diversity of genus Quercus L., Springer, 137-193, Cham.

- Gimeno, T., B. Pias, J. P. Lemos-Filho, F. Valladares, 2009: Plasticity and stress tolerance override local adaptation in the responses of Mediterranean holm oak seedlings to drought and cold, Tree Physiol, 29: 87-98.

- Gratani, L.,M. Meneghini, P. Pesoli, M. F. Crescente, 2003: Structural and functional plasticity of Quercus ilex seedlings of different provenances in Italy, Trees-Struct Funct, 17: 515-521.

- Lamont, B. B., P. K. Groom, R.M. Cowling, 2002: High leaf mass per area of related species assemblages may reflect low rainfall and carbon isotope discrimination rather than low phosphorus and nitrogen concentrations, Funct Ecol, 16: 403-412.

- Mediavilla, S., A. Escudero 2003: Stomatal responses to drought at a Mediterranean site: A comparative study of co-occurring woody species differing in leaf longevity, Tree Physiol, 23: 987996.

- Nardini, A., M. A. Lo Gullo, P. Truifilo, S. Salleo, 2014: The challenge of the Mediterranean climate to plant hydraulics: responses and adaptations, Environ Exp Bot, 103: 68-79.

- Niinemets, Ü., 2015: Is there a species spectrum within the world-wide leaf economics spectrum? Major variations in leaf functional traits in the Mediterranean sclerophyll Quercus ilex, New Phytol, 205: 79-96.

- Niinemets, Ü., A. Díaz-Espejo, J. Flexas, J. Galmés, C.R. Warren, 2009: Role of mesophyll diffusion conductance in constraining potential photosynthetic productivity in the field, J Exp Bot, 60: 2249-2270.

- Niinemets, Ü., T. Keenan, 2014: Photosynthetic responses to stress in Mediterranean evergreens: mechanisms and models, Environmental and Experimental Botany 103: 24-41.

- Niinemets, Ü., 2001: Global-scale climatic controls of leaf dry mass per area, density,and thickness in trees and shrubs, Ecology, 82: 453-469.

- Peguero-Pina, J. J., D. Sancho-Knapik, E. Barrón, J. J. Camarero, A. Vilagrosa, E. Gil-Pelegrín, 2014: Morphological and physiological divergences within Quercus ilex support the existence of different ecotypes depending on climatic dryness, Ann Bot, 114: 301-313.

- Peguero-Pina, J. J., S. Sisó, J. Flexas, J. Galmés, Ü. Niinemets, D. Sancho-Knapik, E. Gil-Pelegrín, 2017: Coordinated modifications in mesophyll conductance, photosynthetic potentials and leaf nitrogen contribute to explain the large variation in foliage net assimilation rates across Quercus ilex provenances, Tree Physiol, 37: 1084-1094.

- Peppe, D. J., D. L. Royer, B. Cariglino, S.Y. Oliver, S. Newman, E. Leight, G. Enikolopov, M. Fernandez-Burgos, F. Herrera, J. M. Adams et al., 2011: Sensitivity of leaf size and shape to climate: global patterns and paleoclimatic applications, New Phytol, 190: 724-739.

- Pérez-Harguindeguy, N., S. Diaz, E. Garnier, S. Lavorel, H. Poorter, P Jaureguiberry, M. S. Bret-Harte, W. K. Cornwell, J. Craine, D. Gurvich, C. Urcelay, E. Veneklaas, P. Reich, L. Poorter, I. J. Wright, P. Ray, L. Enrico, J. G. Pausas, A. C. Vos, J. Cornelissen, 2013: New handbook for standardise measurement of plant functional traits worldwide. Aust J Bot, 61: 167-234.

- Reich, P. B., I. J. Wright, C. H. Lusk, 2007: Predicting leaf physiology from simple plant and climate attributes: a global Glopnet analysis, Ecology, 17: 1982-1988.

- Sardans, J., J. Peñuelas, 2013: Plant-soil interactions in Mediterranean forest and shrublands: impacts of climatic change, Plant Soil 365: 1-33.

- Seletković, Z., I. Tikvić, M. Vučetić, D. Ugarković, 2011: Klimatska obilježja i vegetacija sredozemne Hrvatske, U: S. Matić (ur.), Šume hrvatskog Sredozemlja, Akademija šumarskih znanosti, 142-156, Zagreb.

- Sever, K., S. Bogdan, J. Franjić, Ž. Škvorc, 2018: Nedestruktivna procjena koncentracije fotosintetskih pigmenata u lišću hrasta lužnjaka (Quercus robur L.), Šumar list, 142: 247-257.

- Sever, K., M. Hrust, Ž. Škvorc, S. Bogdan, I. Seletković, N. Potočić, J. Franjić, 2016: Pouzdanost procjene stanja ishrane hrasta lužnjaka (Quercus robur L.) s dušikom pomoću prijenosnog klorofilmetra CCM-200, Šumar list, 140: 465-475.

- Sultan, S. E., 2000: Phenotypic plasticity for plant development, function and life history, Trends Plant Sci, 5: 537-542.

- TIBCO Software Inc. 2018: Statistica (data analysis software system), version 13. http://tibco.com.

- Traiser C, S. Klotz, D. Uhl, V. Mosbrugger, 2005: Environmental signals from leaves - a physiognomic analysis of European vegetation, New Phytol, 166: 465-484.

- Valladares, F., L. Balaguer, E. Martınez-Ferri, E. Perez-Corona, E. Manrique, 2002: Plasticity, instability and canalization: is the phenotypic variation in seedlings ofsclerophyll oaks consistent with the environmental unpredictability of Mediterranean ecosystems? New Phytol, 156: 457-467.

- Valladares, F., E. Ferri-Martinez, L. Balaguer, E. Perez-Corona, E. Manrique, 2000: Low leaf-level response to light and nutrients in Mediterranean evergreen oaks: aconservative resourceuse strategy? New Phytol, 148: 79.-91.

- Varone, L., M. Vitale, R. Catoni, L. Gratani, 2016: Physiological differences of five Holm oak (Quercus ilex L.) ecotypes growing under common growth conditions were related to native local climate, Plant Spec Biol, 31: 196-210.

- WinFolia TM, 2001: Regent Instruments Inc., Quebec, Canada, version PRO 2005b.

- Wright, I. J., P. B. Reich, J. C. Cornelissen, D. S. Falster, P. K. Groom, K. Hikosaka, W. Lee, C. H. Lusk, Ü. Niinemets, J. Oleksyn, et al., 2005: Modulation of leaf Economic traits and trait relationships by climate, Global Ecol Biogeogr, 14: 411-421.

- Wright, I. J., P. B. Reich, M. Westoby, D. D. Ackerly, Z. Baruch, F. Bongers, et al. 2004: The world-wide leaf economics spectrum, Nature, 428: 821-827. 


\section{SUMMARY}

Holm oak (Quercus ilex L.) is an evergreen tree species with natural distribution within the Mediterranean, from Portugal and Morocco on the west to the western coast of Turkey on the east part of its range. On the eastern coast of the Adriatic Sea, it occupies warmer localities on the coast of Istria and northern Adriatic islands while on the southern Adriatic islands as well as on the narrower coastal area south of Zadar it has a more continuous distribution. Given the size of the area of distribution, holm oak shows a big morphological and functional variability so certain populations differ according to the climate conditions in their area. This fact has been very well researched in the western and central part of its range, while the data for the eastern part, and thus for the eastern coast of the Adriatic Sea, are scarce. The great morphological and functional variability of holm oak reflects its great phenotypic plasticity. Although phenotypic plasticity is conditioned by the environment, it can also have a genetic basis through local adaptation to the established environmental conditions in different parts of the species' area of distribution. The aim of this study was to determine whether there is a differentiation of holm oak down the climatic gradient of the eastern Adriatic coast with respect to the functional characteristics of its leaves.

The research was conducted on three provenances of holm oak from the area of Pula and Zadar in the Republic of Croatia and Bar in Montenegro. During the winter of 2019, 12 leaves were sampled per 12 trees in each provenance in order to determine the specific leaf area (SLA). Additionally, acorns were collected beneath those trees with which an greenhouse experiment was established. In the experiment, a total of 64 plants were grown, of which 22 plants from the provenances of Pula and Zadar, and 20 plants from the provenance of Bar. In the second part of the vegetation period in 2020, one leaf was sampled from each plant with the aim of determining the specific leaf area (SLA). In addition, the rate of net photosynthesis (A) and the relative total chlorophyll content index (CCI) were measured in the greenhouse experiment. Measurements were performed in July and September of 2020. A was measured using a portable gas exchange measuring device LCpro + (ADC BioScentific, 2007), while the CCI was measured using the CCM-200 (Opti-Sciences, Tyngsboro, MA).

Analysis of the variance revealed a statistically significant difference among the studied provenances for most of the measured characteristics both on the leaves sampled in the natural habitat and on the young plants in the experimental plantation. Previous research on holm oak indicates that there is a functional differentiation of provenances on different climatic gradients in the central and western Mediterranean, with our results confirming this on the eastern coast of the Adriatic Sea. Young plants in the experimental plantation retain the same pattern of differentiation with respect to SLA as their mother trees in natural stands (Figure 1c). Such a result indicates that the differentiation of holm oak provenances is at least partly the result of genetic adaptation to local habitat conditions, i.e. that the holm oak on the eastern Adriatic coast as well as in other parts of its range could distinguish ecotypes. The sclerophilicity of the leaves described by SLA (Figure 1c) does not coincide with the average annual rainfall (Figure 1a), but with the amount of precipitation in the summer (Figure 1b) and the climate deficit of moisture (Figure 2a). The established pattern of provenance differentiation with respect to SLA and climatic conditions is followed by A measured on young plants in the experimental plantation. Therefore, Pula, which has the highest SLA and comes in the least arid climatic conditions, has the lowest A, while Zadar, which has the lowest SLA and comes in the most arid conditions, shows the highest values of A (Figures 1 and 2). This is in line with the literature that shows that the intensity of photosynthesis per unit leaf area in holm oak decreases with increasing SLA (Niinemets 2015, Peguero-Pina et al. 2017). Namely, the anatomical structure of holm oak leaves is adapted in such a way that those leaves that have a lower SLA also have better conductivity of $\mathrm{CO} 2$ through the mesophilic leaves and contain more nitrogen per unit area. Accordingly, the provenances of Zadar and Bar compared to the provenance of Pula had a lower SLA (Figure 1c) and a higher CCI (Figure 2b) which has a positive correlation with the nitrogen content in the leaves.

Holm oak could have a significant ability to functionally adapt to different climatic conditions. Accordingly, when considering the impact of climate change on natural populations of holm oak, its phenotypic plasticity should be considered, as well as the observed functional ecotypic differentiation.

KEY WORDS: Quercus ilex L., sclerophilic leaf, specific leaf area, rate of net photosynthesis, climate 